\title{
Hot foam and hot water for weed control: A comparison
}

\author{
Luisa Martelloni, Christian Frasconi, Mino Sportelli, Marco Fontanelli, Michele Raffaelli, \\ Andrea Peruzzi
}

Department of Agriculture, Food and Environment, University of Pisa, Pisa, Italy

\begin{abstract}
Thermal weed control plays an important role in managing weeds in synthetic herbicide-free systems, particularly in organic agriculture and in urban areas where synthetic herbicides are prohibited. This study compares the impact on weed control of increased doses of hot water and hot foam (i.e. 0, 0.67, 1.67, 3.33, $5.00,6.67$ and $8.33 \mathrm{~kg} \mathrm{~m}^{-2}$ ). The doses were applied using the same machine. The temperatures, weed control effectiveness, weed regrowth after the death of the aboveground vegetative weed tissues, and weed dry biomass 30 days after the treatments were studied in two experimental fields with a different weed composition (i.e. Site I and Site II). The results showed that difficult weeds to control, such as Cynodon dactylon (L.) Pers., Digitaria sanguinalis (L.) Scop. and Taraxacum officinale Weber, like all the other species in the initial weed populations in the two experiments, died after lower doses of hot foam compared to hot water. Adding foam to hot water made it possible to lower the required dose of water by at least 2.5-fold compared to hot water used alone. By insulating the weeds, the foam led to higher peak temperatures and slower temperature decay, thus determining an effective weed control with lower doses compared to hot water. Starting from 11 days and 16 days after treatments (for Site I and Site II, respectively), there were no statistically significant differ-
\end{abstract}

Correspondence: Christian Frasconi, Department of Agriculture, Food and Environment, University of Pisa, via del Borghetto 80, 56124 Pisa, Italy. E-mail: christian.frasconi@unipi.it

Key words: Alternative methods; dose; integrated weed management; herbicide-free; no-chemical; thermal weed control.

Acknowledgements: this study was self-financed by the Department of Agriculture, Food and Environment of the University of Pisa (Pisa, Italy). The authors would like to thank Cosmin User, Franck Balducchi and Edward Cutler from the Weedingtech Ltd. who provided the hot foam machine and technical support; Lorenzo Greci and Romano Zurrida from the Department of Agriculture, Food and Environment of University of Pisa for their technical support.

Conflict of interests: the authors declare no potential conflict of interests.

Received for publication: 5 March 2021

Accepted for publication: 29 June 2021.

(C) Copyright: the Author(s), 2021

Licensee PAGEPress, Italy

Journal of Agricultural Engineering 2021; LII:1167

doi:10.4081/jae.2021.1167

This article is distributed under the terms of the Creative Commons Attribution Noncommercial License (by-nc 4.0) which permits any noncommercial use, distribution, and reproduction in any medium, provided the original author(s) and source are credited. ences in weed regrowth between hot foam and hot water at all the doses applied. There were no differences between the dry biomass of weeds collected 30 days after treatments when the same doses of hot foam and hot water were used.

\section{Introduction}

In Europe today there are increasing concerns regarding herbicide resistance and residues from herbicides found in surface water. New regulations are being promoted to limit the dependence on synthetic herbicides, which can be dangerous to human health and the environment, thus alternative methods for controlling weeds are urgently needed (Cederlund and Börjesson, 2016; Hansson and Matsson, 2002; De Cauwer et al., 2014, 2016).

Thermal weed control methods such as hot water and flaming play an important role in managing weeds, particularly in organic agriculture and in urban areas, where the use of herbicides is forbidden or not recommended. Moreover, thermal weed control methods do not lead the selection of herbicide-resistant populations (Raffaelli et al., 2013; Martelloni et al., 2016; Melander et al., 2017). The use of hot water eliminates the fire hazard associated with flame weeding (Hansson and Ascard, 2002). Several factors influence the heat injury of the plants, including temperature, energy input, exposure period, and weed species (Peerzada and Chauhan, 2018).

Thermal weed control involves heat being transferred to plant material (leaves, stems, flowers, propagules, etc.) to destroy cell structures and denature proteins (Cederlund and Börjesson, 2016; Melander et al., 2017). To control aboveground vegetation with thermal weed control methods, the heat requirement depends on the weed species, their growth stages, water status, and the presence of moisture on the leaf surface (Melander et al., 2017). The dose applied is critical and determines the efficacy of the weed control. Appropriate doses (expressed as liquified petroleum gas fuel or water mass per unit area) can therefore increase the overall efficiency (Cederlund and Börjesson, 2016). When hot water is used, the amount of energy that can be transferred to the weeds per unit of time increases with the increasing water flow (Hansson and Matsson, 2002). A wetting agent increases the contact surface between the hot water applied and the weeds, and improves the conditions for heat transfer into the plant (Matthews, 2000). In New Zealand, one treatment using hot water equipment for landscape and roadside vegetation management killed most annual weeds and young perennial weeds, but older perennial weeds required repeated treatments (Daar, 1994). Studies of hot water for weed control in orchards have shown that a travel speed of up to $6 \mathrm{~km} \mathrm{~h}^{-1}$ resulted in a good control of broad-leaved weeds, and two or three treatments per season were necessary (Kurfess and Kleisinger, 2000). The addition of a wetting agent to hot water enhances hot water efficiency (Hansson and Matsson, 2002). When weeds are controlled by hot water, laboratory experiments have shown that the speed of application can be increased by adding a surfactant to the water (Kurfess and Kleisinger, 2000).

Hot foam was first patented in 1995 and represents an evolution of the hot water weed control method, modified by the addi- 
tion of biodegradable foaming agents (Cederlund and Börjesson, 2016; Rajamannan, 1996). Hot foam weed control has limited risks to the environment and human health and is applicable to numerous weed species (Wei et al., 2010). The foam insulates the weeds from the surrounding air and increases the energy transfer to the plants, thus lowering the dose of hot water required and increasing efficiency (Cederlund and Börjesson, 2016). Compared to hot water alone, the addition of foam requires less water, has a lower susceptibility to weather changes, a high application accuracy and speed as well as a low cost (Peerzada and Chauhan, 2018; Wei et al., 2010). The aboveground vegetative tissues of weeds can be effectively controlled by hot water and hot foam (Hansson and Matsson, 2002; Martelloni et al., 2019, 2020). In fact, most thermal methods affect the aboveground portion of the plants, however some weeds (i.e., perennial weeds) may regrow from their belowground components (Peerzada and Chauhan, 2018; Kup and Saglam, 2014). The regrowth of weeds after the death of the aboveground vegetative tissues is an important indicator in validating the effectiveness of a weed control technique. Given that a technique should kill the weeds after being applied, the time weeds take to regrow and cover the ground again is an indicator of how many times the technique needs to be repeated in the annual management of weeds (Martelloni et al., 2020). To the best of our knowledge, there has been no research comparing different doses of hot foam and hot water to control weeds. The aim of this study was to compare the effect on weed control of increased doses of hot water and hot foam (i.e. 0, 0.67, 1.67, 3.33, 5.00, 6.67 and 8.33 $\mathrm{kg} \mathrm{m}^{-2}$ ). The temperatures, weed control effectiveness, weed regrowth after the death of the aboveground vegetative tissues, and weed dry biomass 30 days after the application of treatments were studied in two experimental fields characterized by a different weed composition.

\section{Materials and methods}

\section{Experimental set up, design and treatment}

A two-site experiment was conducted on fields with two different weed compositions at the experimental farm of the University

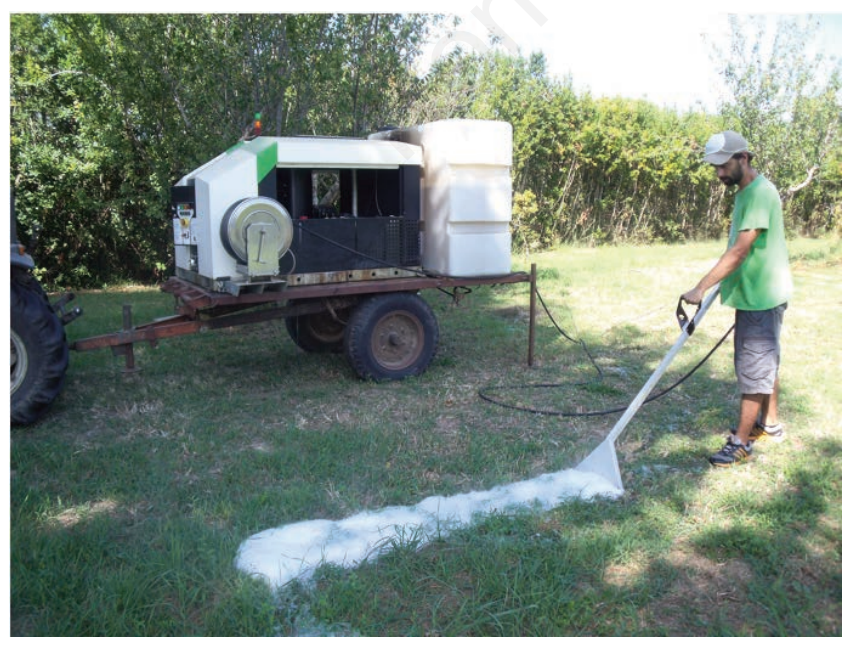

Figure 1. Hot foam machine: operator using the hot foam distribution tool and lateral view of the machine with the $1000 \mathrm{~L}$ water container, the covered part containing the foam container, the boiler, the programmable logic controller, the pump and the diesel generator set. of Pisa (Pisa, Italy) (4340’33.1” N 10¹8’41.2” E). In Site I the main weeds were Cynodon dactylon (L.) Pers., Festuca arundinacea Schreb., Convolvulus arvensis L. and Digitaria sanguinalis (L.) Scop. Together these species accounted for $90 \%$ (in terms of plant cover) of the weed community. The most developed plants of C. dactylon had eight visible tillers (stage 28), F. arundinacea had four visible tillers (stage 24), C. arvensis had 10 true leaves (stage 19 ) and D. sanguinalis had seven visible tillers (stage 27) (Hess et al., 1997). Other weeds randomly present in the plots were, Potentilla reptans L., Ranunculus ficaria L., Sonchus oleraceus L. and Trifolium repens L. giving an overall total of $10 \%$ (in terms of plant cover) of the weed community.

In Site II, the main weeds were $C$. dactylon and Taraxacum officinale Weber, which accounted for $50 \%$ and $40 \%$ of the weed community, respectively (in terms of plant cover). The maximum growth stage of $T$. officinale was eight true-leaves (stage 18), and C. dactylon was five tillers visible (stage 25) (Hess et al., 1997). Other weeds randomly present were Cichorium intybus L., Cyperus esculentus L., Convolvulus arvensis L., D. sanguinalis, Echinochloa crus-galli (L.) Beauv., Hypochaeris radicata L., Plantago major L., P. reptans, $R$. ficaria, Rumex obtusifolius L., S. oleraceus, T. repens, giving an overall total of $10 \%$ of the weed community. The identification of weed species and percentages of single species in the total weed population were based on visual estimates. The sites were selected as they had a homogenous distribution of the main weeds described. The soil was loam in both sites (which differed for weed composition). The sites were not tilled (i.e., meadows under orchards) and the weeds were managed periodically with mowing before the experiments were carried out.

Hot foam was applied using the Foamstream ${ }^{\circledR}$ MW Series machine (Weedingtech Ltd., London, UK) (Figure 1) (Weedingtech, 2019a). The foaming solution used (Foamstream V4) was a $100 \%$ blend of plant oils and sugar (e.g., alkyl polyglucoside surfactants) (Weedingtech, 2019b). The emission class was equivalent to the Euro 5 stage (Nesbit et al., 2016). Hot water was applied using the same machine by disconnecting the supply pipe of the foaming solution and the temperature at lance was about

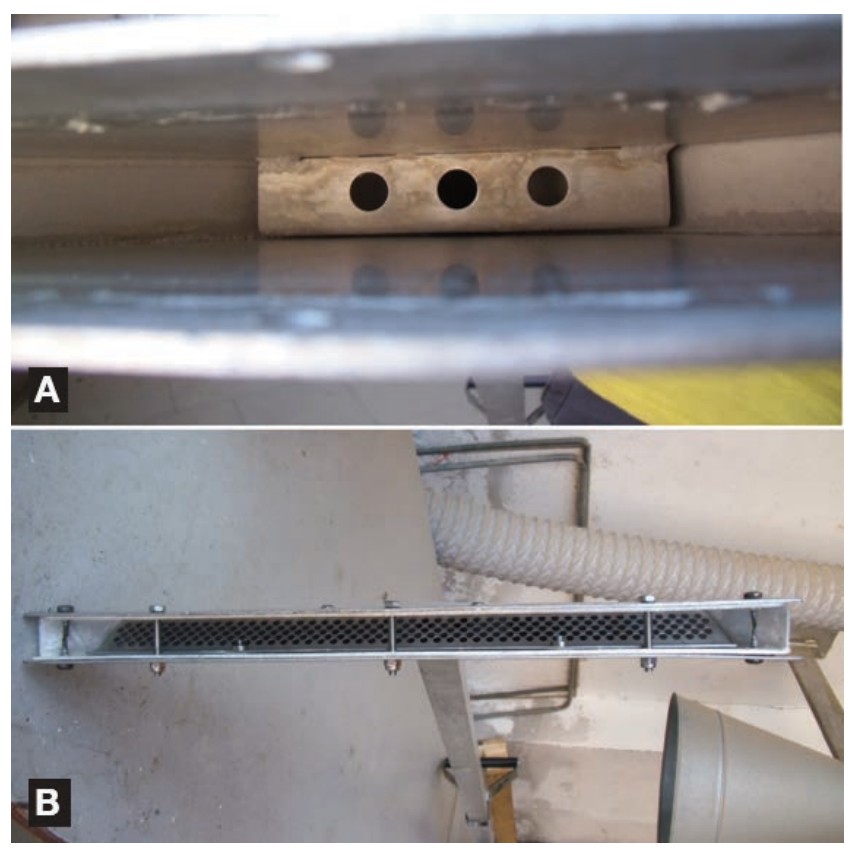

Figure 2. Hot foam distribution tool: A) outlet holes, B) grid mounted next to the outlet holes to ensure a homogeneous distribution of the hot foam. 
$98^{\circ} \mathrm{C}$ (Weedingtech, 2019b). Hot foam and hot water were applied manually with a $0.3 \mathrm{~m}$ wide distribution tool (Figure 2) by following notch references in the soil. Plots $2 \mathrm{~m}$ long and $0.3 \mathrm{~m}$ wide (according to the working width of the distribution tool) were covered in $2,5,10,15,20,25 \mathrm{~s}$, respectively, by positioning the notches every $1 \mathrm{~s}$ to be covered. The distribution tool was operated at 5 $\mathrm{mm}$ from the ground with the help of the carter of the lance. The same machine and the same distribution tool were used to apply the hot foam and hot water in order to avoid any variability caused by using different machines.

Doses measured in volume were 6.45-fold higher when hot foam was applied compared to hot water, while the water mass was the same. The treatments were applied on 16 September 2019. The cumulative rainfall in September and October 2019 was $56 \mathrm{~mm}$ and $147 \mathrm{~mm}$, respectively, and the average temperature was $22^{\circ} \mathrm{C}$ and $18^{\circ} \mathrm{C}$, respectively. The experimental design at each site was a randomized block design with three blocks. In each block, seven hot foam doses and seven hot water doses were applied (i.e. 0, $0.67,1.67,3.33,5.00,6.67$ and $8.33 \mathrm{~kg} \mathrm{~m}^{-2}$, the water mass was the same for both treatments) for a total of 42 plots per site.

\section{Data collection}

The temperature of the hot foam and hot water for each dose was measured with a 4-channel digital thermometer (PCE-T 390, PCE Inst., Southampton, UK) equipped with four type K thermocouples and an SD card data logger (PCE group, 2019), which were placed on the soil surface of the dedicated plots before treatment application. Temperatures were recorded every second from the peak to the constant temperature (i.e., the environment temperature). Each thermocouple provided a replicate of the measurement.

Measurements of the ground covered by weeds were used to estimate weed control (i.e. from treatment application to death of aboveground weed tissues) and weed regrowth (i.e. from death of aboveground weed tissues to 29 days after treatment). These measurements were estimated from digital images using the IMAGING Crop Response Analyser (IMAGING Crop Response Analyser, 2019) online software. The digital images were taken from two areas of $0.075 \mathrm{~m}^{2}(25 \times 30 \mathrm{~cm})$ per plot at the same geographical coordinates. Photographs of the weed cover for evaluating the devitalisation were taken 1 day before, and 1 and 2 days after treatments. Weed cover photographs to assess regrowth were taken at 3, 7, 11, 16, 21, 25 and 29 days after treatments. The distance between the weeds and the camera was constant (i.e. $30 \mathrm{~cm}$ from the ground). High contrast was avoided by using an umbrella. The brightness of the digital images was equalized before analysis. The digital image analysis was performed as described in Rasmussen et al. (2007), by assessing the percentage of green pixels from the total number of pixels in the photograph. Weed species were visually identified from the photographs, but statistical analysis was conducted only on the total weed population, in order to compare the effect of hot foam and hot water in a real field infested by multiple weeds.

The green weed biomass was collected 30 days after the treatment from two areas of $0.075 \mathrm{~m}^{2}(25 \times 30 \mathrm{~cm})$ per plot by cutting the weeds at ground level. Cut plants were dried at $105^{\circ} \mathrm{C}$ to a constant weight, and then the dry weight was converted into $\mathrm{g} \mathrm{m}^{-2}$.

\section{Statistical analysis}

Student's $t$-test was used to verify that the error mean was not significantly different from zero. Error distribution normality was verified using the Shapiro-Wilk test. Other tests consisted of the BreuschPagan test to verify the residuals homoscedasticity and the Durbin-
Watson test to verify the absence of autocorrelation in residuals.

Weed cover data collected one day before, and one, two, three, $7,11,16,21,25$ and 29 days after treatments were modelled in a linear mixed model using the $\mathrm{R}$ software ( $\mathrm{R}$ Core Team, 2016) extension package 'ImerTest' (Tests in Linear Mixed Effects Models) (Kuznetsova, 2016). A logit transformation was conducted. The dose $\left(0,0.67,1.67,3.33,5.00,6.67\right.$ and $\left.8.33 \mathrm{~kg} \mathrm{~m}^{-2}\right)$, treatment (hot foam and hot water), and evaluation date (one day before, and one and two days after treatments for the evaluation of weed control and 3, 7, 11, 16, 21, 25 and 29 days after treatments for the evaluation of weed regrowth) were the fixed factors. Fitted correlations among the slopes were assessed in the random factors. Weed dry biomass data collected 30 days after treatments were modelled in a linear mixed model using the $\mathrm{R}$ software ( $\mathrm{R}$ Core Team, 2016) extension package 'ImerTest' (Tests in Linear Mixed Effects Models). The dose (0, 0.67, 1.67, 3.33, 5.00, 6.67 and 8.33 $\mathrm{kg} \mathrm{m}^{-2}$ ) and the treatment (hot foam and hot water) were the fixed factors. Fitted correlations among the slopes were assessed in the random factors. Each site was analysed separately. The analysis of variance was conducted. The extension package 'ggplot2' (elegant graphics for data analysis) (Wickham, 2009) was used to plot the bar graphs.

The percentage weed cover as affected by hot foam and hot water doses two days after the treatments was modelled using a three-parameter log-logistic nonlinear regression (Equation 1) model (Seber and Wild, 1989):

$$
Y=\frac{d}{\{1+\exp [b(\log X-\log e)]\}}
$$

where $(Y)$ is the response (percentage weed cover), $(d)$ is the percentage weed cover in the control (i.e. dose of $0 \mathrm{~kg} \mathrm{~m}^{-2}$ ), (b) is the slope of the curve at the inflection point, $(X)$ is the predictor (hot foam and hot water doses), and (e) represents the dose providing $50 \%$ control of the initial weed coverage. A model for each site was used.

The decay in temperature after hot foam and hot water application as affected by the dose was modelled using a three-parameter exponential decay nonlinear regression model (Equation 2) (OECD, 2006):

$$
Y=c+(d-c)\left(\exp \left(-\frac{X}{e}\right)\right)
$$

where $(Y)$ is the response (temperature), $c$ : is the temperature for time going to infinity; $d$ : is the temperature at time $0 \mathrm{~s}$ (e.g., peak temperature); $(X)$ is the predictor (time in seconds), and $(e)$ is the slope of the decay. As temperature increases linearly, the heatkilling time of weeds is known to decrease exponentially (Levitt, 1980; Martelloni et al., 2019).

A significance test comparing the dose-response model and the simple linear regression model with slope 0 (a horizontal regression line corresponding to no dose effect) was not significant $(\mathrm{P}<0.001)$ for any of the models (Eq. 1), indicating a highly significant effect of the dose. The 'drc' (dose-response curves) R extension (Ritz et al., 2015) was used to fit the nonlinear regression model, to estimate the parameters, the effective doses and times, the relative potency, and to plot the non-linear regression curves.

The comparisons between pairs of estimated values were computed by estimating the $95 \%$ confidence interval of the difference between the values (Equation 3): 


$$
C I \text { (difference) }=\left(x_{1}-x_{2}\right) \pm 1.96 \sqrt{\left(S E_{X_{1}}\right)^{2}+\left(S E_{X_{2}}\right)^{2}}
$$

where $\left(x_{1}\right)$ is the mean of the first value, $\left(x_{2}\right)$ is the mean of the second value, $\left(\mathrm{SE} x_{1}\right)$ is the standard error of $\left(x_{1}\right)$, and $\left(\mathrm{SE} x_{2}\right)$ is the standard error of $\left(x_{2}\right)$. If the resulting $95 \%$ confidence interval $(C I)$ of the difference between values did not cross the value 0 , the null hypothesis that the compared values were not different was rejected.

\section{Results}

\section{Temperature}

Peak temperatures and subsequent exponential decays for each hot foam and hot water dose are plotted in Figure 3 as average of the two sites. The parameters of the non-linear regressions are reported in Table 1 . The effective times needed by each dose to reach $70^{\circ} \mathrm{C}, 60^{\circ} \mathrm{C}$ and $50^{\circ} \mathrm{C}$, respectively, are reported in Table 2 .

Peak temperatures, for both hot foam and hot water, decreased significantly from the highest dose to the lowest dose. The pair hot foam doses of $1.67 \mathrm{~kg} \mathrm{~m}^{-2}$ and $3.33 \mathrm{~kg} \mathrm{~m}^{-2}$, and $3.33 \mathrm{~kg} \mathrm{~m}^{-2}$ and $6.67 \mathrm{~kg} \mathrm{~m}^{-2}$ led to similar peak temperatures $\left(e . g .75^{\circ} \mathrm{C}\right.$ and $\left.85^{\circ} \mathrm{C}\right)$, whereas only the hot water doses of $1.67 \mathrm{~kg} \mathrm{~m}^{-2}$ and $3.33 \mathrm{~kg} \mathrm{~m}^{-2}$ led to similar peak temperatures (e.g. about $60^{\circ} \mathrm{C}$ ) (parameter $d$, Table 1). The significantly highest peak temperature was reached when the highest hot foam dose was used (i.e. $8.33 \mathrm{~kg} \mathrm{~m}^{-2}$ ). The hot foam dose of $6.67 \mathrm{~kg} \mathrm{~m}^{-2}$ led to a similar peak temperature compared to the hot water dose of $8.33 \mathrm{~kg} \mathrm{~m}^{-2}$. All other hot water doses had significantly lower peaks than that reached by the 1.67 $\mathrm{kg} \mathrm{m}^{-2}$ hot foam dose, suggesting a higher heat transfer efficiency of hot foam compared to hot water (parameter $d$, Table 1).

Hot water doses from 0.67 to $5.00 \mathrm{~kg} \mathrm{~m}^{-2}$ did not reach a peak temperature of $70^{\circ} \mathrm{C}$, and doses of $6.67 \mathrm{~kg} \mathrm{~m}^{-2}$ and $8.33 \mathrm{~kg} \mathrm{~m}^{-2}$ took a few seconds (i.e. $0.7 \mathrm{~s}$ and $6.0 \mathrm{~s}$, respectively) to decay to $70^{\circ} \mathrm{C}$. Also, hot foam doses of $1.67 \mathrm{~kg} \mathrm{~m}^{-2}$ and $3.33 \mathrm{~kg} \mathrm{~m}^{-2}$ took a few seconds to decay from the peak to $70^{\circ} \mathrm{C}$, whereas the hot foam dose of $8.33 \mathrm{~kg} \mathrm{~m}^{-2}$ took one minute, and that of $6.67 \mathrm{~kg} \mathrm{~m}^{-2}$ and $5.00 \mathrm{~kg} \mathrm{~m}^{-2}$ took about a half-minute (Table 2). The temperature of $60^{\circ} \mathrm{C}$ was reached after about $12 \mathrm{~s}$ when the highest dose (i.e. 8.33 $\mathrm{kg} \mathrm{m}^{-2}$ ) of hot water was used which was statistically similar to the time taken by the hot foam dose of $1.67 \mathrm{~kg} \mathrm{~m}^{-2}$ to reach $60^{\circ} \mathrm{C}$. The highest dose of hot foam (i.e. $8.33 \mathrm{~kg} \mathrm{~m}^{-2}$ ) led to an enduring temperature from the peak to $60^{\circ} \mathrm{C}$ of almost 2 minutes (Table 2). When the highest dose (i.e. $8.33 \mathrm{~kg} \mathrm{~m}^{-2}$ ) of hot water was used, the

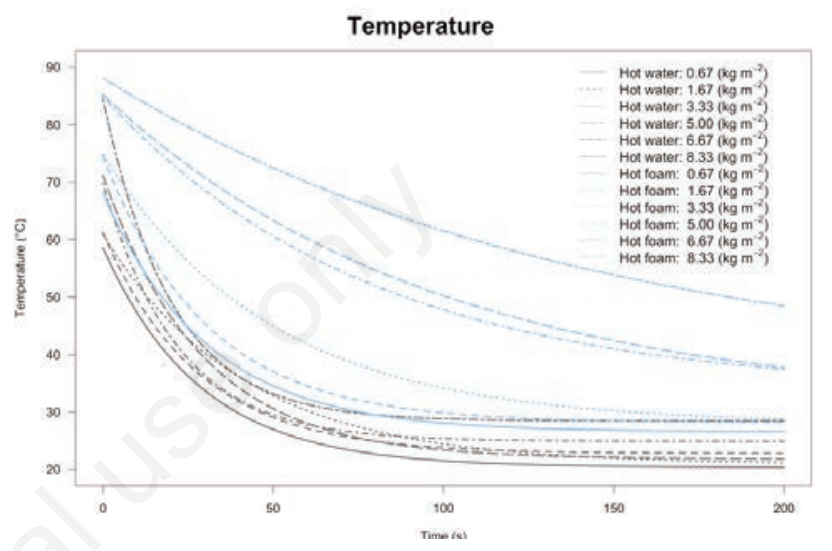

Figure 3. Exponential decay curves of temperature as affected by the dose $\left(0,0.67,1.67,3.33,5.00,6.67\right.$, and $\left.8.33 \mathrm{~kg} \mathrm{~m}^{-2}\right)$ and the treatment (hot foam and hot water) by the passage of time. The parameters of the non-linear regression are reported in Table 1.

Table 1. Parameters of the exponential decay model (Equation (2)) as affected by the dose $(0,0.67,1.67,3.33,5.00,6.67$, and $8.33 \mathrm{~kg}$ $\mathrm{m}^{-2}$ ) and the treatment (hot foam and hot water) by the passage of time. The non-linear regression curves are plotted in Figure 3.

\begin{tabular}{lcccccc} 
Dose $\left(\mathrm{kg} \mathrm{m}^{-2}\right)$ & \multicolumn{3}{c}{ Hot foam parameters $( \pm \mathrm{SE})$} & \multicolumn{3}{c}{ Hot water parameters $( \pm$ SE) } \\
c & d & e & & d \\
0.67 & $26.53(0.05)$ & $68.10(0.42)$ & $30.33(0.51)$ & $20.37(0.046)$ & $58.60(0.45)$ & $28.45(0.57)$ \\
1.67 & $28.15(0.05)$ & $74.47(0.40)$ & $30.25(0.42)$ & $22.75(0.046)$ & $61.23(0.46)$ & $27.65(0.57)$ \\
\hline 3.33 & $28.01(0.05)$ & $74.86(0.31)$ & $49.11(0.53)$ & $20.90(0.05)$ & $60.90(0.37)$ & $41.25(0.66)$ \\
5.00 & $33.44(0.06)$ & $84.92(0.27)$ & $78.11(0.73)$ & $24.90(0.04)$ & $69.80(0.51)$ & $21.94(0.43)$ \\
\hline 6.67 & $30.80(0.06)$ & $85.25(0.23)$ & $96.99(0.75)$ & $21.82(0.05)$ & $71.18(0.45)$ & $28.91(0.45)$ \\
8.33 & $35.96(0.09)$ & $88.13(0.21)$ & $139.98(1.23)$ & $28.45(0.04)$ & $84.45(0.48)$ & $20.15(0.27)$ \\
\hline
\end{tabular}

c, temperature for time going to infinity; d, temperature at time 0 s (e.g. peak temperature); e, slope of the decay; SE, standard error.

Table 2. Effective times estimated for reaching temperatures of $70^{\circ} \mathrm{C}, 60^{\circ} \mathrm{C}$ and $50^{\circ} \mathrm{C}\left(\mathrm{ET}_{70}, \mathrm{ET}_{60}\right.$, and $\mathrm{ET}_{50}$, respectively) after the application of different hot foam and hot water doses. The non-linear regression curves are plotted in Figure 3 . The parameters of the non-linear regression are reported in Table 1.

\begin{tabular}{|c|c|c|c|c|c|c|}
\hline \multirow[t]{2}{*}{ Dose $\left(\mathrm{kg} \mathrm{m}^{-2}\right)$} & \multicolumn{3}{|c|}{ Hot foam effective times (s) ( \pm SE) } & \multicolumn{3}{|c|}{ Hot water effective times $(s)( \pm S E)$} \\
\hline & ET70 & $\mathrm{ET}_{60}$ & $\mathrm{ET}_{50}$ & $\mathrm{ET}_{70}$ & $\mathrm{ET}_{60}$ & ET50 \\
\hline 0.67 & NA & $6.57(0.11)$ & $17.34(0.29)$ & NA & NA & $7.25(0.14)$ \\
\hline 1.67 & $3.07(0.04)$ & $11.33(0.16)$ & $22.73(0.32)$ & NA & $0.90(0.02)$ & $9.54(0.20)$ \\
\hline 3.33 & $5.38(0.06)$ & $18.74(0.20)$ & $37.14(0.40)$ & NA & $0.94(0.02)$ & $13.13(0.21)$ \\
\hline 5.00 & $26.74(0.25)$ & $51.71(0.48)$ & $88.62(0.83)$ & NA & $5.40(0.10)$ & $12.76(0.25)$ \\
\hline 6.67 & $31.86(0.25)$ & $60.43(0.47)$ & $101.09(0.79)$ & $0.70(0.01)$ & $7.43(0.11)$ & $16.21(0.25)$ \\
\hline 8.33 & $59.76(0.53)$ & $108.45(0.95)$ & $183.73(1.62)$ & $6.01(0.08)$ & $11.56(0.16)$ & $19.25(0.26)$ \\
\hline
\end{tabular}

$\mathrm{NA}$, not available (i.e. the estimation had no biological meaning). 
temperature of $50^{\circ} \mathrm{C}$ was reached after about $19 \mathrm{~s}$, which was significantly lower than the time taken by the hot foam dose of 1.67 $\mathrm{kg} \mathrm{m}^{-2}$ to reach the same temperature. The highest dose of hot foam (i.e. $8.33 \mathrm{~kg} \mathrm{~m}^{-2}$ ) led to an enduring temperature from the peak to $50^{\circ} \mathrm{C}$ of about 3 minutes (Table 2).

\section{Weed control}

In Site I, the analysis of variance showed that weed control was affected by the dose, evaluation date, and the interaction between dose and evaluation date, dose and treatment, evaluation date and treatment $(\mathrm{P}<0.0001)$. In Site II, the interaction between dose, evaluation date, and treatment was also significant $(\mathrm{P}<0.0001)$. Back-transformed least square means and the $95 \%$ confidence interval of percentage weed cover as affected by dose, treatments and evaluation date are reported in Figure 4.

In both sites, weed cover before the treatments was statistically similar in all the plots (Figure 4). One day after the treatment, the aboveground vegetative tissues were in a desiccation phase, and not all the aboveground vegetative tissues of killed weeds had already turned brown. The weed control effect of dose and treatment was visible two days after the hot foam and hot water application (Figure 4). Least square means and standard errors of weed cover two days after treatments are reported in Table 3.

In Site I, two days after treatment, the dose of $0.67 \mathrm{~kg} \mathrm{~m}^{-2}$ did not control weeds after either the hot foam or the hot water (Figure 4 , Table 3 ). In fact, the weed cover after this dose was statistically similar to that of the control. Doses from 1.67 to $6.67 \mathrm{~kg} \mathrm{~m}^{-2}$ led to a significantly higher weed control effect using the hot foam compared to hot water. Weed cover after hot foam treatment was on average $0.8 \%, 0.2 \%, 0.1 \%$ and $0.1 \%$, when doses of $1.67,3.33$, 5.00 and $6.67 \mathrm{~kg} \mathrm{~m}^{-2}$ were used, respectively. After hot water, weed cover was on average $8.1 \%, 1.1 \%, 2.8 \%$ and $0.3 \%$, when doses of $1.67,3.33,5.00$ and $6.67 \mathrm{~kg} \mathrm{~m}^{-2}$ were used, respectively. At the highest dose (i.e. $\left.8.33 \mathrm{~kg} \mathrm{~m}^{-2}\right)$ the level of weed control $(0 \%$ weed cover, i.e. $100 \%$ weed control) was similar comparing the hot foam and hot water (Figure 4, Table 3). With the hot foam, the

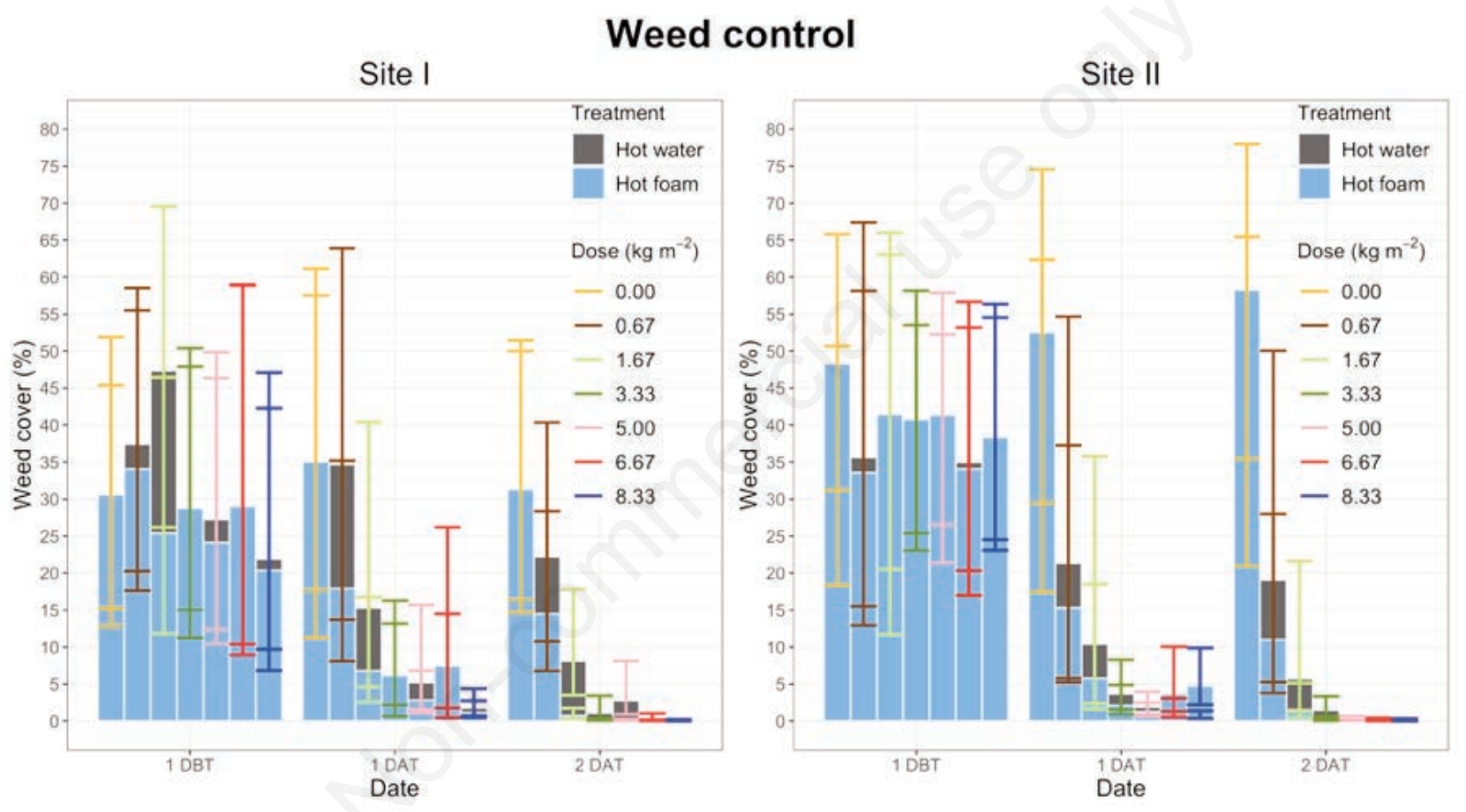

Figure 4. Back-transformed least squares means and $95 \%$ confidence interval bars of percentage weed cover as affected by the dose $(0$, $0.67,1.67,3.33,5.00,6.67$ and $8.33 \mathrm{~kg} \mathrm{~m}^{-2}$ ), treatment (hot foam and hot water) and evaluation date (one day before, and one and two days after treatment) in Site I and Site II, respectively. DBT, days before treatment; DAT, days after treatment.

Table 3. Least square means and standard error of percentage weed cover logit transformed estimated from the linear mixed models (Site I and Site II, respectively) two days after treatment application, as affected by dose and treatment.

\begin{tabular}{lllll} 
Doses $\left(\mathrm{kg} \mathrm{m}^{-2}\right)$ & & \multicolumn{2}{l}{ logit Weed cover (\%)] $( \pm$ SE) } & Site II \\
& Hot foam & Site I & Hot foam & $-0.35(0.44)$ \\
0.00 & $-0.79(0.42)$ & $-0.88(0.43)$ & $0.33(0.42)$ & $-1.45(0.58)$ \\
0.67 & $-1.78(0.43)$ & $-1.25(0.43)$ & $-4.09(0.49)$ & $-2.80(0.59)$ \\
\hline 1.67 & $-4.88(0.43)$ & $-2.43(0.44)$ & $-6.93(0.39)$ & $-4.20(0.39)$ \\
3.33 & $-6.42(0.44)$ & $-4.49(0.52)$ & $-6.92(0.34)$ & $-5.71(0.36)$ \\
5.00 & $-7.18(0.51)$ & $-3.56(0.52)$ & $-8.28(0.46)$ & $-6.38(0.41)$ \\
6.67 & $-7.48(0.50)$ & $-5.77(0.54)$ & $-8.68(0.37)$ & $-6.51(0.35)$ \\
\hline
\end{tabular}


highest levels of weed control were reached using doses from 5.00 to $8.33 \mathrm{~kg} \mathrm{~m}^{-2}$. With these doses, the weed covers were statistically similar and significantly lower than with the other doses. With the hot water, the highest levels of weed control were reached using $6.67 \mathrm{~kg} \mathrm{~m}^{-2}$ and $8.33 \mathrm{~kg} \mathrm{~m}^{-2}$. At these doses, weed covers were statistically similar and significantly lower than with the other doses (Table 3). Differences in weed soil coverage between treatments were mostly due to $D$. sanguinalis, which had a major cover after hot water compared to hot foam, when doses up to $6.67 \mathrm{~kg} \mathrm{~m}^{-2}$ were applied. Aboveground vegetative tissues of other weed species were all killed after $3.33 \mathrm{~kg} \mathrm{~m}^{-2}$ of hot foam and $5.00 \mathrm{~kg}$ $\mathrm{m}^{-2}$ of hot water.

In Site II, two days after treatment, the dose of $0.67 \mathrm{~kg} \mathrm{~m}^{-2}$ controlled only a little percentage of weeds (percentage weed cover was on average $11 \%$ ) only after hot foam application, whereas, after hot water, the weed cover at $0.67 \mathrm{~kg} \mathrm{~m}^{-2}$ was similar to that of the control. However, the weed covers after the application of $0.67 \mathrm{~kg} \mathrm{~m}^{-2}$ of hot foam and hot water were statistically similar. The doses from $1.67 \mathrm{~kg} \mathrm{~m}^{-2}$ to $8.33 \mathrm{~kg} \mathrm{~m}^{-2}$ led to a significantly higher level of weed control using hot foam compared to hot water.
Weed cover after hot foam was on average $1.5 \%, 0.1 \%, 0.1 \%, 0 \%$ and $0 \%$, when doses of $1.67,3.33,5.00,6.67$ and $8.33 \mathrm{~kg} \mathrm{~m}^{-2}$ were used, respectively. After hot water, weed cover was on average $5.7 \%, 1.5 \%, 0.3 \%, 0.2 \%$ and $0.1 \%$, when doses of $1.67,3.33,5.00$, 6.67 and $8.33 \mathrm{~kg} \mathrm{~m}^{-2}$ were used, respectively. With hot foam, the highest levels of weed control were reached using the doses of 6.67 and $8.33 \mathrm{~kg} \mathrm{~m}^{-2}$. At these doses, weed cover was statistically similar and significantly lower than when the other doses were applied. With hot water, the highest level of weed control was reached using the dose $8.33 \mathrm{~kg} \mathrm{~m}^{-2}$, when weed cover was significantly lower compared with the other doses (Table 3 ). T. officinale was still present after all the hot water doses, whereas after hot foam, it was only present up to doses of $5.00 \mathrm{~kg} \mathrm{~m}^{-2}$. C. dactylon disappeared from plots after the application of $5.00 \mathrm{~kg} \mathrm{~m}^{-2}$ of hot water and after $3.33 \mathrm{~kg} \mathrm{~m}^{-2}$ of hot foam. Aboveground vegetative tissues of other weed species were all killed after $1.67 \mathrm{~kg} \mathrm{~m}^{-2}$ of hot foam and $3.33 \mathrm{~kg} \mathrm{~m}^{-2}$ of hot water.

Percentage weed cover two days after the treatment (i.e. when aboveground tissues of the plants had turned brown) as a function of the dose followed a log-logistic regression decay. The log-logis-

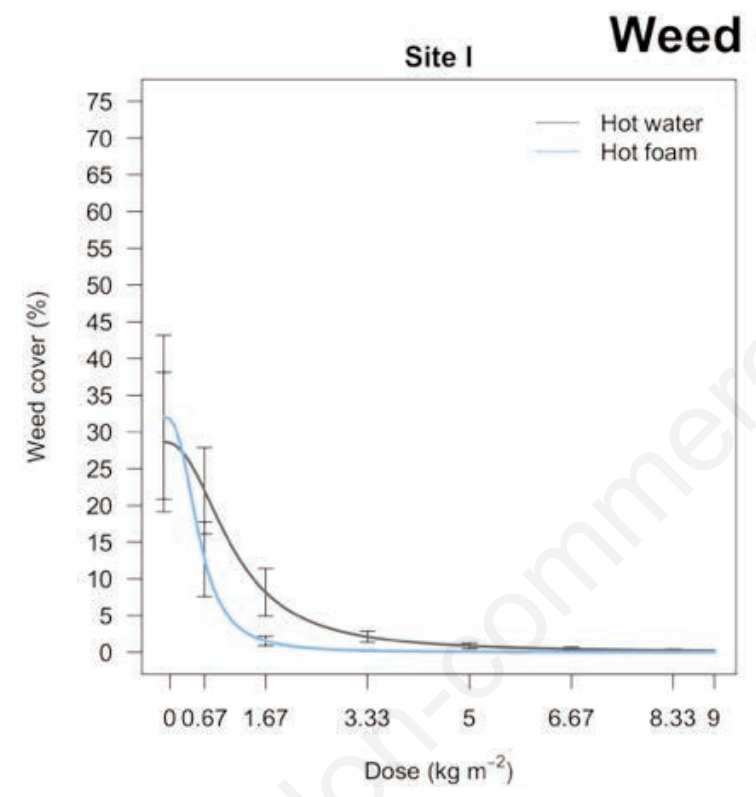

control

Site II

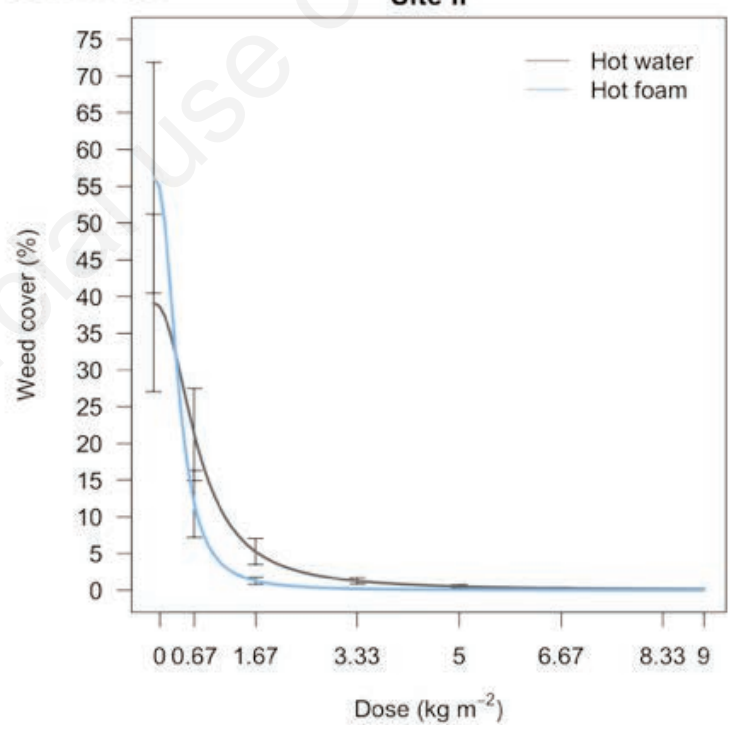

Figure 5. Log-logistic regression curves with model-based $95 \%$ confidence interval bars of weed cover percentage as affected by hot foam and hot water doses $\left(0,0.67,1.67,3.33,5.00,6.67\right.$, and $\left.8.33 \mathrm{~kg} \mathrm{~m}^{-2}\right)$ two days after treatment in the two experiment sites (Site $I$ and Site II). The parameters of the non-linear regression curves (Equation 1) are reported in Table 4.

Table 4. Parameters and standard errors (SE) of the log-logistic regression model (Equation 1$)$ and effective doses $\left(\mathrm{kg} \mathrm{m}^{-2}\right)$ estimated two days after treatments for reducing the initial weed cover by $10 \%, 90 \%$ and $99 \%$ as affected by treatments (i.e. hot foam and hot water) in the two sites. The non-linear regression curves are plotted in Figure 5.

\begin{tabular}{|c|c|c|c|c|c|c|}
\hline \multirow[t]{2}{*}{ Dose $\left(\mathrm{kg} \mathrm{m}^{-2}\right)$} & \multicolumn{3}{|c|}{ Parameters ( \pm SE) } & \multicolumn{3}{|c|}{ Effective dose $\left(\mathrm{kg} \mathrm{m}^{-2}\right)( \pm \mathrm{SE})$} \\
\hline & $b$ & $d$ & $e$ & $\mathrm{ED}_{10}$ & ED90 & ED99 \\
\hline Hot foam & $2.79(0.29)$ & $32.01(5.60)$ & $0.57(0.09)$ & $0.26(0.06)$ & $1.26(0.15)$ & $2.97(0.37)$ \\
\hline \multirow[t]{2}{*}{ Hot water } & $2.32(0.31)$ & $28.64(4.78)$ & $1.12(0.24)$ & $0.43(0.14)$ & $2.89(0.38)$ & $8.15(1.21)$ \\
\hline & $b$ & $d$ & $e$ & $\mathrm{ED}_{10}$ & $\mathrm{ED}_{25}$ & ED99 \\
\hline Hot foam & $2.64(0.23)$ & $56.16(7.90)$ & $0.40(0.06)$ & $0.18(0.04)$ & $0.93(0.09)$ & $2.30(0.23)$ \\
\hline Hot water & $2.21(0.23)$ & $39.12(6.07)$ & $0.72(0.14)$ & $0.27(0.08)$ & $1.94(0.25)$ & $5.74(0.71)$ \\
\hline
\end{tabular}

$b$, is the slope of the curve at the inflection point; $d$, is the percentage weed cover in the control (i.e. dose of $0 \mathrm{~kg} \mathrm{~m}^{-2}$ ); e, represents the dose providing $50 \%$ control of the initial weed coverage (i.e. $50 \%$ weed cove between the upper and the lower limit of the curve at the inflection point). 
tic regression curves and the effective doses (ED), which led to $10 \%, 90 \%$ and $99 \%$ of the initial weed coverage, are reported in Figure 5. The regression parameters and the effective doses that led to $10 \%, 90 \%$ and $99 \%$ of the initial weed coverage are reported in Table 4.

The weed cover at the zero dose (i.e. the control) was statistically similar between hot foam and hot water in both sites (parameter $d$, Table 4). At the highest dose used (i.e. $8.33 \mathrm{~kg} \mathrm{~m}^{-2}$ ) both hot foam and hot water led to $100 \%$ weed control (i.e. $0 \%$ weed cover), thus a three-parameter model was used because the $c$ parameter (i.e. the lower limit of the curve) of the four-parameter model was statistically similar to 0 . The concept of parallelism (Finney, 1978), which implied similar slopes and limits for hot foam and hot water, was respected (parameter $b$ and $d$, Table 4 ) and the relative potencies (relative potency $=E D_{\text {hot water }} / \mathrm{ED}_{\text {hot foam }}$ ) between the two treatments were studied.

The relative potencies of the treatments were $1.66( \pm 0.66)$ and $1.52( \pm 0.53)$ (for Sites I and II, respectively) at $10 \%$ weed cover reduction, and $1.96( \pm 0.52)$ and $1.78( \pm 0.44)$ at $50 \%$ weed cover reduction. These indices were not all significant (i.e. the $95 \%$ confidence interval crossed the 1 value), suggesting that a similar dose of hot foam and hot water was required to reduce the initial weed cover by $10 \%$ and $50 \%$. In contrast, the relative potencies to reduce the initial weed cover by $90 \%$ and $99 \%$ were significant, indicating that a higher dose of hot water compared to hot foam was needed to obtain the same level of weed reduction. The relative potencies were $2.30( \pm 0.40)$ and $2.10( \pm 0.34)$ (for Sites I and II, respectively) at the $90 \%$ weed cover reduction level, and $2.75( \pm 0.53)$ and 2.50 $( \pm 0.40)$ (for Sites I and II, respectively) at the $99 \%$ weed cover reduction level. Therefore, the hot water dose required was on average 2.3 and 2.1-fold higher (for Sites I and II, respectively) compared to the dose of hot foam, in order to reduce the initial weed cover by $90 \%$, and 2.75 and 2.50 -fold higher (for Sites I and II, respectively) in order to reduce the initial weed cover by $99 \%$ (Table 4).

\section{Weed regrowth}

In Site I, the analysis of variance showed that weed regrowth was affected by the dose, evaluation date ( $\mathrm{P}<0.0001$, respectively), treatment $(\mathrm{P}=0.039)$ and the interaction between dose and evaluation date, dose and treatment $(\mathrm{P}<0.0001$, respectively), evaluation date and treatment $(\mathrm{P}=0.026)$. In Site II, weed regrowth was affected by the dose, evaluation date ( $\mathrm{P}<0.0001$, respectively), treatment $(\mathrm{P}=0.033)$ and the interaction between dose and evaluation date, dose and treatment, evaluation date and treatment $(\mathrm{P}<0.0001$, respectively). Back-transformed least square means and the $95 \%$ confidence interval of percentage weed cover as affected by dose, treatments and evaluation date are reported in Figure 6.
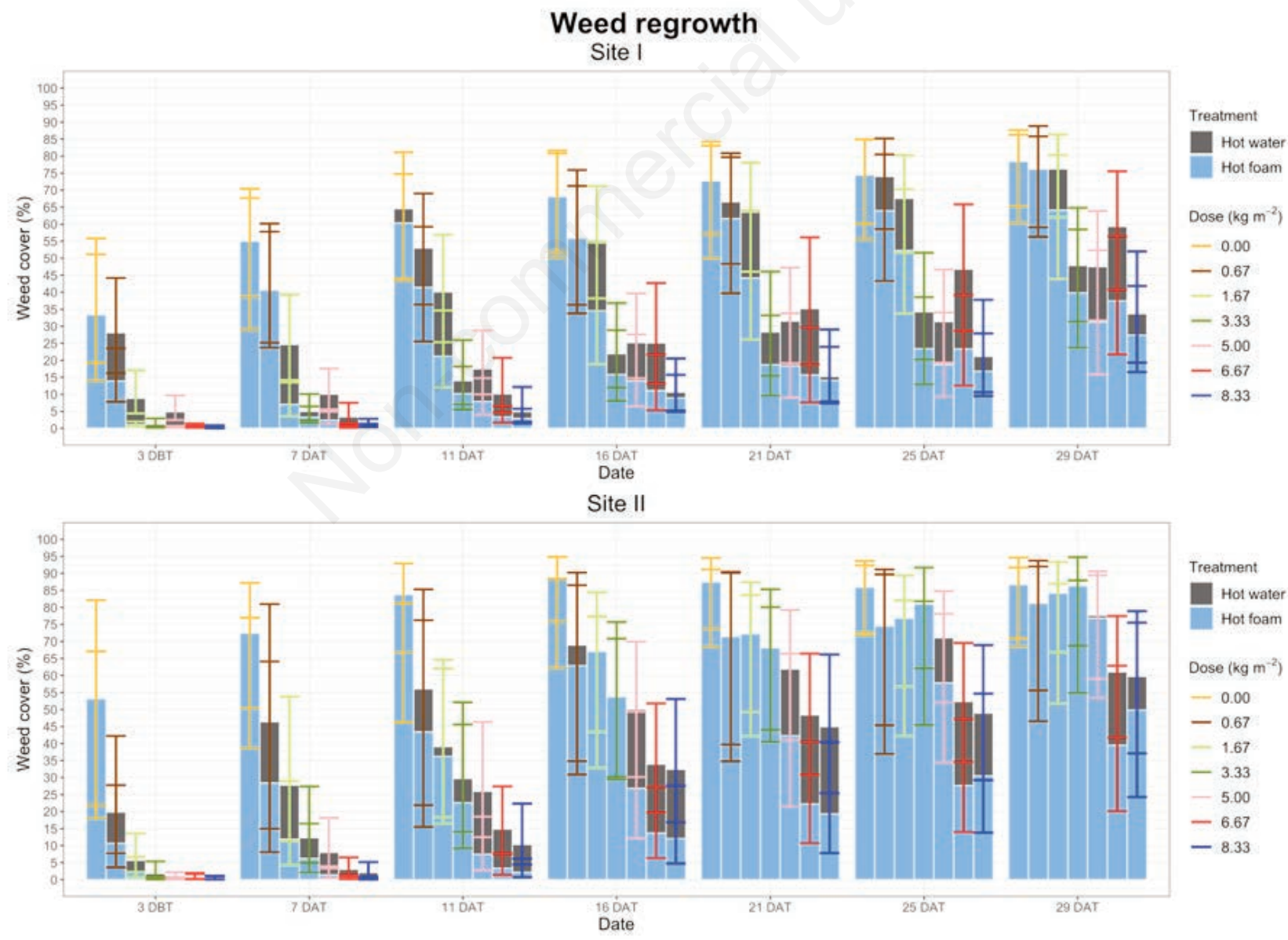

Figure 6. Back-transformed least squares means and $95 \%$ confidence interval bars of percentage weed cover as affected by the dose $(0$, $0.67,1.67,3.33,5.00,6.67$ and $\left.8.33 \mathrm{~kg} \mathrm{~m}^{-2}\right)$, treatment (hot foam and hot water) and evaluation date $(3,7,11,16,21,25$ and 29 days after treatment) in Site I and Site II, respectively. DAT, days after treatment. 
As expected, at each dose of hot foam and hot water used, weeds re-covered the ground significantly from three days to 29 days after treatment (Figure 6). Starting from 11 days and 16 days after treatments (respectively, for Site I and Site II), there were no statistically significant differences in percentage weed cover between hot foam and hot water at all the doses applied (Figure 6).

The cover of soil by weeds at doses that did not lead to $100 \%$ death of the aboveground weed tissues (i.e. in Site I, from 0.67 to $6.67 \mathrm{~kg} \mathrm{~m}^{-2}$ for both hot water and hot foam, and in Site II, from 0.67 to $5.00 \mathrm{~kg} \mathrm{~m}^{-2}$ for hot foam and all doses of hot water) was due to the continuous natural growth of surviving weeds, the regrowth from the non-damaged meristems, and the growth of new weeds from seeds. In plots where the weed control was $100 \%$ (i.e. in Site I, the dose of $8.33 \mathrm{~kg} \mathrm{~m}^{-2}$ for both hot water and hot foam, and in Site II the hot foam doses of 6.67 and $8.33 \mathrm{~kg} \mathrm{~m}^{-2}$ ) the regrowth was only due to the non-damaged meristems and seeds, which colonized plots.

In Site I, the first weeds to re-sprout were $C$. dactylon, $F$. arundinacea and $D$. sanguinalis. Starting from 11 days after treatments, seedlings of $G$. dissectum, and re-sprouts of $C$. arvensis and P. reptans were oberved in all plots. In the subsequent evaluation dates, seedling of $S$. alba (Miller) Krause, T. repens and $V$. persica were also observed. At the highest doses used (i.e. 6.67 and $8.33 \mathrm{~kg} \mathrm{~m}^{-}$ ${ }^{2}$ ) for both hot water and hot foam, the final composition of the weed community was different compared to the start of the experiment, and G. dissectum had colonized the plots. This weed, together with $C$. dactylon, $F$. arundinacea and D. sanguinalis, accounted for $90 \%$ of the final total weed population. C. arvensis was drastically reduced ( $2 \%$ of total weeds) compared to before the treatments, and was one of the main weeds only in the control and at the lowest doses applied (i.e. 0.67 and $1.67 \mathrm{~kg} \mathrm{~m}^{-2}$ ).

In Site II, C. dactylon (L.) and T. officinale were the first weeds to re-sprout. Eleven days after treatments, first occurrences of seedlings of $C$. esculentus, $S$. media, T. repens, $V$. persica and resprouts of $C$. arvensis, $P$. reptans and $R$. ficaria were observed. The final weed composition at the highest doses used (i.e. 6.67 and $8.33 \mathrm{~kg} \mathrm{~m}^{-2}$ ) for both hot water and hot foam changed compared to before the start of the experiment with C. esculentus and T. officinale being the main weeds. $C$. dactylon had decreased ( $1 \%$ of total weeds) compared to before the treatments and was one of the main weeds only in the control and at the lowest doses (i.e. 0.67 and 1.67 $\mathrm{kg} \mathrm{m}^{-2}$ ).

\section{Weed dry biomass}

Figure 7 reports the least square means and the 95\% confidence interval of weed dry biomass as affected by dose and treatment. In both sites, the analysis of variance showed that weed dry biomass collected 30 days after treatment was affected only by the dose $(\mathrm{P}<0.0001)$. In fact, at the same doses, there were no differences between the dry biomass of weeds 30 days after the application of either hot foam or hot water (Figure 7). Differences were observed only among doses applied. In both sites, a dose of 8.33 $\mathrm{kg} \mathrm{m}^{-2}$ led to a statistically lower dry biomass compared to the control, whereas 0.67 and $1.67 \mathrm{~kg} \mathrm{~m}^{-2}$ led to a similar biomass compared to $3.33,5.00$ and $6.67 \mathrm{~kg} \mathrm{~m}^{-2}$ (Figure 7).

\section{Discussion}

Peak temperatures after thermal treatment decreased from the highest doses to the lowest doses (Hansson and Matsson, 2002). In our experiments, the amount of water per unit of time was changed by changing the forward speed of the machine and ensuring a constant water flow. The highest doses used led to a higher transfer of energy than the lowest dose and this is valid in open field condi-

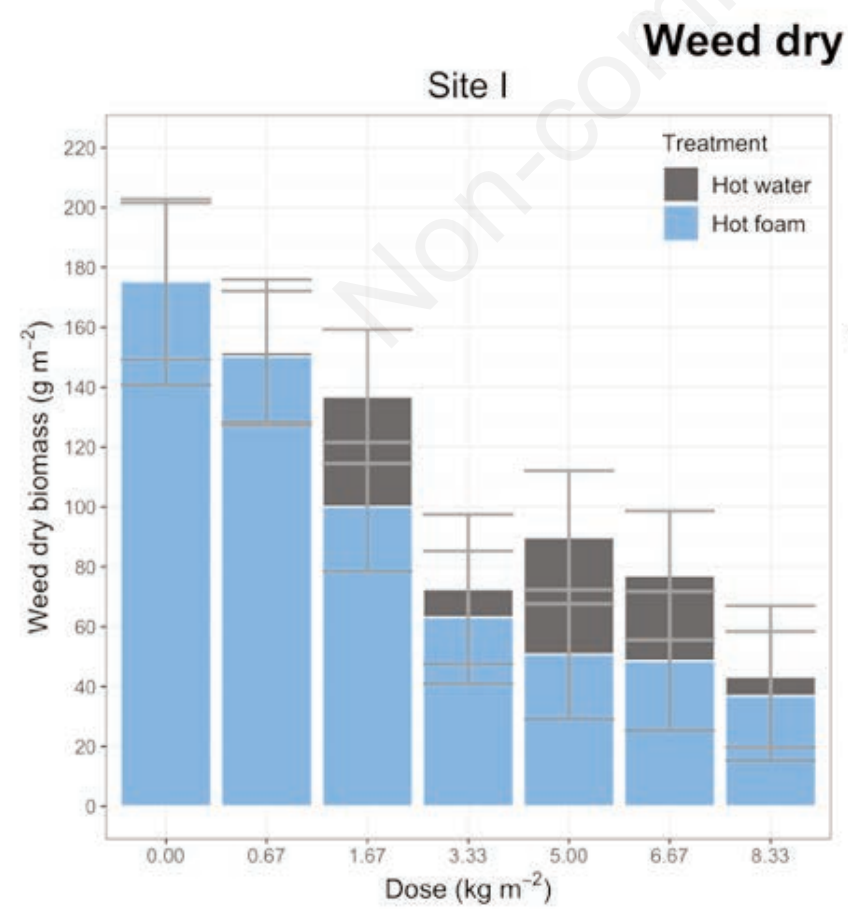

biomass

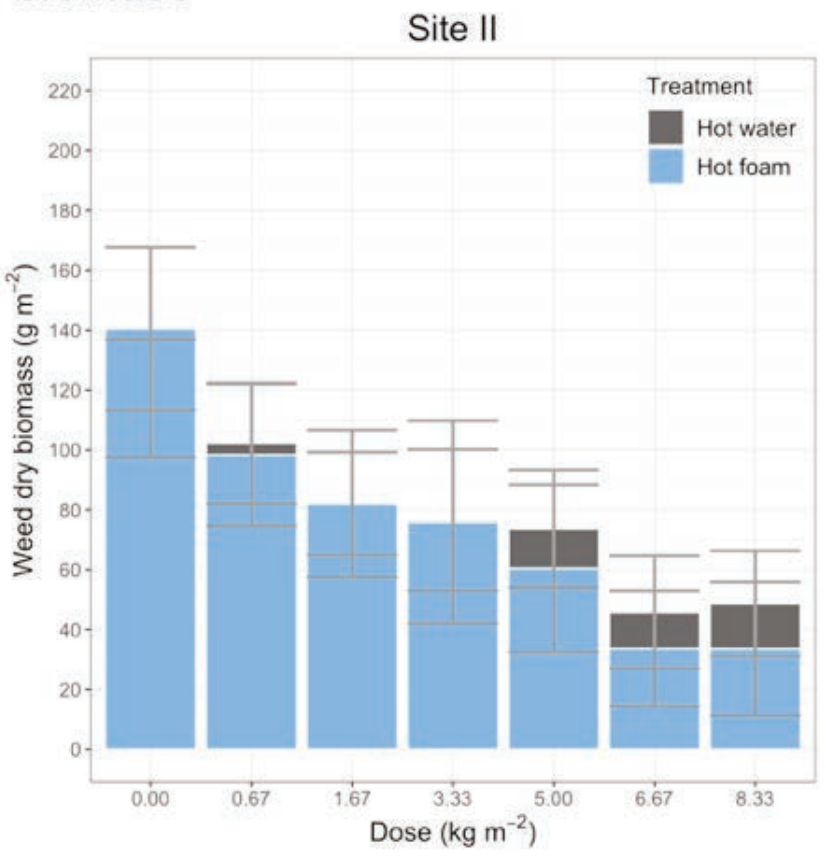

Figure 7. Least squares means and $95 \%$ confidence interval bars of weed dry biomass collected 30 days after treatments, as affected by the dose $\left(0,0.67,1.67,3.33,5.00,6.67\right.$ and $\left.8.33 \mathrm{~kg} \mathrm{~m}^{-2}\right)$ and treatment (hot foam and hot water) in Site I and Site II, respectively. 
tions with all the variability involved.

All the hot foam doses showed significantly higher peak temperatures compared to the same doses of water applied, suggesting that the addition of the wetting agent to water to generate foam increased the heat transfer efficiency of the hot water. The foam insulates the weeds from the surrounding air and increases the energy transfer efficiency to the plants (Cederlund and Börjesson, 2016). Adding foam to hot water can allow to reduce the dose of water required compared to hot water used alone in order to obtain the same energy transfer efficiency and subsequent weed control effectiveness. This was confirmed in this study by the results of the relative potency between the hot foam and hot water which for hot water showed the need for a 2.5-fold and 2.7-fold higher dose (respectively for Site I and Site II and depending on the weed population composition) to reach the same level of weed control (e.g. 99\% weed control) compared to hot foam (Table 4).

C. dactylon, D. sanguinalis and T. officinale were found to be less sensitive to hot water compared to hot foam, because the weed cover differences between the two treatments at the highest doses in the two experiments were due to these species. Plant response to heat is known to be species-dependent (Ascard, 1995). Weed leaf tissue death requires less heat exposure time when the maximum temperature (i.e. peak temperature) increases. Both generative and vegetative propagules of most weed species are killed within a temperature range of 60 to $80^{\circ} \mathrm{C}$ (Melander et al., 2017). The duration of heating needed to reach mortality is determined by thermal conductivity, and a high maximum temperature can be effective in few seconds (Melander et al., 2017). Hot foam reached higher maximum temperatures compared to hot water with the same dose because of its slower heat dissipation due to its insulating effect. Therefore, the foam led to higher peak temperatures and slower temperature decay by insulating the weeds, eventually resulting in an effective weed control with lower doses compared to hot water (Tables 1, 2 and 4).

Weed regrowth, over time, was more influenced by the dose than by the use of hot foam or hot water. In fact, starting from 11 days and 16 days after treatments (respectively, for Site I and Site II), the differences between the two methods were no longer significant (Figure 6). In real field conditions, where the re-sprouting from meristems was added to the emergence from seeds, 29 days were sufficient to allow a weed to grow and cover the soil, even if the growth started from a $100 \%$ weed-free soil (such as when the dose of $8.33 \mathrm{~kg} \mathrm{~m}^{-2}$ was used in Site I, and hot foam doses of 6.67 and $8.33 \mathrm{~kg} \mathrm{~m}^{-2}$ were used in site II). Many plants with protected meristems, such as grasses and perennial weeds, can regrow after non-chemical treatments (Melander et al., 2009). In this experiment, weeds growing from seeds and from meristems were not analysed separately. However, from a visual evaluation of the photographs, at the highest doses (i.e. 6.67 and $8.33 \mathrm{~kg} \mathrm{~m}^{-2}$ ), the number of weeds from seeds seemed higher than those re-sprouting from meristems. In previous studies an increase in the dose of hot foam led to an increase in the injury to weed meristems and the delay of re-growth (Martelloni et al., 2019).

Because weeds can regrow, they need to be eliminated by consecutive treatments (De Cauwer et al., 2014). When the highest dose of both hot foam and hot water was used (i.e. $8.33 \mathrm{~kg} \mathrm{~m}^{-2}$ ), 29 days after the treatment, the weed cover was similar to that of the control before the start of the experiments (Figures 4 and 6), thus suggesting the need for a new application. Hansson and Ascard (2002) found that the required application interval between hot water weed control treatments was 25 days. Other authors have reported that three to five hot water treatments are required throughout a growing season to keep weeds under control (Kempenaar and Spijker, 2004; Vermeulen et al., 2006; Rask et al., 2013; De Cauwer et al., 2014). It is evident that if hot foam, com- pared to hot water, reduces the dose of water required by at least 2.5 -fold for the same $99 \%$ weed control effect (as found in these experiments), the use of hot foam is more favourable. This is very important because a lower dose leads accordingly to a lower water and fuel consumption (for this machine is $8 \mathrm{~L}$ of diesel per hour). A lower dose also means accordingly a shorter operative time. The speed of the treatment varied from $0.08 \mathrm{~m} \mathrm{~s}^{-1}$ to $1 \mathrm{~m} \mathrm{~s}^{-1}$ by a working width of $0.3 \mathrm{~m}$. The hot foam can be effectively applied in urban hard surfaces and green areas, but also in integrated and organic agriculture (e.g. vineyard trellis, orchards, vegetables).

\section{Conclusions}

Hot foam insulated the weeds and led to a higher heat transfer efficiency compared to hot water used alone. Adding foam to hot water reduced the hot water dose and obtained the same level of weed control effectiveness. The reductions in the doses that led to a 99\% weed control were 2.5-fold and 2.7-fold in Site I and Site II, respectively. The regrowth of weeds after treatments occurred both after hot foam and hot water, and one month after the treatments there were no differences in percentage weed cover and weed dry biomass between the two thermal methods applied. This also suggests that with the highest doses there were no significant differences in the injuries caused to the weed meristems. In addition, as the experiments were conducted in real field conditions (and not in the laboratory), with the passage of time the ground was colonized by weeds from seeds, which influenced the final percentage weed cover and weed dry biomass. Because the differences in the effectiveness of the aboveground weed control between hot foam and hot water were successfully studied in this experiments, future studies could focus on a quantitative study of the injuries or damage caused to the below-ground portion of weeds.

\section{References}

Ascard J. 1995. Effects of flame weeding on weed species at different developmental stages. Weed Res. 35:397-411.

Cederlund H., Börjesson E. 2016. Hot foam for weed control - Do alkyl polyglucoside surfactants used as foaming agents affect the mobility of organic contaminants in soil? J. Hazard. Mater. 314:312-317.

Daar S. 1994. New technology harnesses hot water to kill weeds. IPM Practioner 16:1-5.

De Cauwer B., Bogaert S., Claerhout S., Bulcke R., Reheul D. 2014. Efficacy and reduced fuel use for hot water weed control on pavements. Weed Res. 55:195-205.

De Cauwer B., De Keyser A., Biesemans N., Claerhout S., Reheul D. 2016. Impact of wetting agents, time of day and periodic energy dosing strategy on the efficacy of hot water for weed control. Weed Res. 56:323-34.

Finney D.J. 1978. Statistical method in biological assay. Charles Griffin \& Co. Ltd., London, UK.

Hansson D., Ascard J. 2002. Influence of development stage and time of assessment on hot water weed control. Weed Res. 42:307-16.

Hansson D., Matsson J.E. 2002. Effect of drop size, water flow, wetting agent and water temperature on hot-water weed control. Crop Prot. 21:773-81.

Hess M., Barralis G., Bleiholder H., Buhr L., Eggers T.H., Hack H., Stauss R. 1997. Use of the extended BBCH scale - general for the description of the growth stages of mono- and dicotyledonous weed species. Weed Res. 37:433-41. 
IMAGING Crop Response Analyser. Ver. 0.4. 2018. Available from: http://imaging-crops.dk Accessed: 17 July 2019.

Kempenaar C., Spijker J.H. 2004. Weed control on hard surfaces in the Netherlands. Pest management. Science 60:595-9.

Kup F, Saglam R. 2014. Weed destruction in cotton fields using hot foam method and its comparison to certain other methods. ARPN J. Agric. Biol. Sci. 9:301-7.

Kurfess W., Kleisinger S. 2000. Effect of hot water on weeds. Proceedings of the 20th German Conference on weed biology and weed control. Stuttgart, Hohenheim, Germany, 14-16 March. Zeitschrift für Pflanzenkrank-heiten, Pflanzenkrank 17:473-477.

Kuznetsova A., Brockhoff P.B., Christensen R.H.B. 2016. lmerTest: tests in linear mixed effects models. R package version 2.0-32. Available from: https:/CRAN.R-project.org/package $=$ lmerTest Accessed: 17 July 2019.

Levitt J. 1980. Responses of plants to environmental stresses. Volume II. Water, radiation, salt, and other stresses. Academic Press, London, UK, pp. 607.

Martelloni L., Fontanelli M., Frasconi C., Raffaelli M., Peruzzi A. 2016. Cross-flaming application for intra-row weed control in maize. Appl. Eng. Agric. 32:569-78.

Martelloni L., Frasconi C., Sportelli M., Fontanelli M., Raffaelli M., Peruzzi A. 2019. The use of different hot foam doses for weed Control. Agronomy 9:490.

Martelloni L., Frasconi C., Sportelli M., Fontanelli M., Raffaelli M., Peruzzi A. 2020. Flaming, glyphosate, hot foam and nonanoic acid for weed control: a comparison. Agronomy 10:129.

Matthews G.A. 2000. Pesticide application methods. 3rd Edition. Blackwell Science, London, UK.

Melander B, Holst N., Grundy AC., Kempenaard C., Riemens M.M., Verschwele A., Hansson, D. 2009. Weed occurrence on pavements in five North European towns. Weed Res. 49:516-25.

Melander B., Liebman M., Davis A.S., Gallandt E.R., Bàrberi P., Moonen A.C., Rasmussen J., van der Weide R., Vidotto F. 2017. Non-chemical weed management. Thermal weed control. In Hatcher, P.E. and Froud Williams, R.J. (Eds.), Weed research: expanding horizons. John Wiley \& Sons Ltd., Hoboken, NJ, USA, pp. 259-264.

Nesbit M., Fergusson M., Colsa A., Ohlendorf J., Hayes C., Paquel K., Schweitzer J.P. 2016. Comparative study on the differences between the EU and US legislation on emissions in the automotive sector. European Parliament: Brussel, Belgium. Available from: http://www.europarl.europa.eu/Reg Data/etudes/STUD/2016/587331/IPOL_STU(2016)587331_E
N.pdf

OECD (Organisation for Economic Co-operation and Development). 2006. Current approaches in the statistical analysis of ecotoxicity data: A guidance to application - annexes. OECD, Paris, pp. 80.

PCE group. 2019. PCE-T390 digital thermometer. Available from: https://www.industrial-needs.com/technical-data/digital-thermometer-PCE-T390.html Accessed: 17 July 2019.

Peerzada A.M., Chauhan B.S. 2018. Chapter 2. Thermal weed control: history, mechanisms, and impacts. In Jabran K., Chauhan B.S. (Eds.), Non-chemical weed control. Elsevier, London, UK, pp. 9-31.

R Core Team. R: a language and environment for statistical computing. 2016. R Foundation for Statistical Computing, Vienna, Austria. Available from: https://www.R-project.org/ Accessed: 17 July 2019.

Raffaelli M., Martelloni L., Frasconi C., Fontanelli M., Peruzzi A. 2013. Development of machines for flaming weed control on hard surfaces. Appl. Eng. Agric. 29:663-73.

Rajamannan A.H.J. 1996. Method of using hot air foam to kill vegetation and pests. U.S. Patent No. 5,575,111,19 November.

Rask A.M., Larsen S.U., Andreasen C., Kristoffersen P. 2013. Determining treatment frequency for controlling weeds on traffic islands using chemical and non-chemical weed control. Weed Res. 53:249-58.

Rasmussen J., Norremark M., Bibby B.M. 2007. Assessment of leaf cover and crop soil cover in weed harrowing research using digital images. Weed Res. 47:299-310.

Ritz C., Baty F., Streibig J.C., Gerhard D. 2015. Dose-response analysis using R. PLoS One 10:e146021.

Seber G.A.F., Wild C.J., 1989. Nonlinear regression. Wiley \& Sons, New York, NY, USA, pp 330.

Vermeulen G.D., Verwijs B.R., Kempenaar C. 2006. Effectiveness of weed control methods on pavement. Plant Research International. Wageningen, The Netherlands.

Weedingtech. 2019a. Foamstream M1200. Available from: https://www.weedingtech.com/product/foamstream-m1200/ Accessed: 17 July 2019.

Weedingtech. 2019b. Our Technology. Available from: https://www.weedingtech.com/why-foamstream/our-technology/ Accessed: 17 July 2019.

Wei D., Liping C., Zhijun M., Guangwei W., Ruirui Z. 2010. Review of non-chemical weed management for green agriculture. Int. J. Agric. Biol. Eng. 3:52-60.

Wickham H. 2009. ggplot2: elegant graphics for data analysis, 3rd ed. Springer-Verlag, New York, NY, USA. 